\title{
PROSTITUTION AND VENEREAL DISEASES IN MANCHESTER*
}

\author{
BY \\ SYDNEY M. LAIRD \\ Director, St. Luke's Clinic and V.D. Department, Royal Infirmary, Manchester
}

The relationship between prostitution and the spread of venereal disease probably varies from country to country and, indeed, between the various communities of one country. Many believe that prostitution plays little part in the spread of venereal infection in England (British Social Biology Council, 1955), although Nicol (1956) is of the opinion that the "reservoir" of undetected gonorrhoea in females comprises both the prostitute and the promiscuous "amateur". My own experience suggested that prostitution is an insignificant factor in the smaller provincial towns and rural communities, but it assumes a significant role in the largest cities especially when they are also seaports. This impression was supported by the relevant data from the Gonorrhoea Study of the British Cooperative Clinical Group (B.C.C.G.) modified in Table I.

TABLE I

MALE CASES OF GONORRHOEA INFECTED BY PROSTITUTES (MODIFIED FROM TABLE IV OF THE B.C.C.G. GONORRHOEA STUDY)

\begin{tabular}{|c|c|c|c|c|c|}
\hline \multirow[b]{2}{*}{$\begin{array}{l}\text { Source of } \\
\text { Infection }\end{array}$} & \multicolumn{5}{|c|}{ Group } \\
\hline & $\begin{array}{c}\text { I. } \\
\text { Ports }\end{array}$ & $\begin{array}{l}\text { II. } \\
\text { Inland } \\
\text { Indus- } \\
\text { trial } \\
\text { Cities }\end{array}$ & $\begin{array}{c}\text { III. } \\
\text { London }\end{array}$ & $\begin{array}{c}\text { IV. } \\
\text { Quiet } \\
\text { Areas }\end{array}$ & Total \\
\hline All Cases & 2,926 & 962 & 2,001 & 115 & 6,004 \\
\hline $\begin{array}{c}\text { No. Infected by } \\
\text { Prostitutes }\end{array}$ & 1,332 & 69 & 462 & 30 & 1,893 \\
\hline $\begin{array}{l}\text { Infected by Prosti- } \\
\text { tutes (per cent.) }\end{array}$ & 45 & 7 & 23 & 26 & 31 \\
\hline
\end{tabular}

The total of the four groups in Table I also shows that 31 per cent. of 6,004 male cases of gonorrhoea were infected by prostitutes. This figure may, however, be significantly weighted by seafarers infected by prostitutes abroad and may not reflect fairly the position in the ports in which these seafarers were treated. The B.C.C.G. Gonorrhoea Study was a retrospective analysis and details of the sources of infection had not been fully recorded in all cases.

\section{Present Study}

A detailed study of the epidemiological and social factors relating to venereal diseases was planned in Manchester in 1954 primarily to collect information

\footnotetext{
* Received for publication July 27, 1956.
}

on which to develop greater control activities. As full information as possible has been recorded for each person with recent sexual exposure attending the two largest V.D. Clinics in Manchester-St. Luke's Clinic and the V.D. Clinic of the Manchester Royal Infirmary. This information, in addition to being entered on the patient's records, has been transcribed to a special register to facilitate subsequent analysis. The data collected during the year ending June 30, 1956, have been studied, and information regarding the role of the prostitute in the spread of venereal disease in Manchester is presented below.

Syphilitic infections have been excluded from the study as the number is so small. However, minor conditions requiring treatment and those cases seeking reassurance after exposure to infection, which together form a not unimportant part of the work of the V.D. clinics, have been included with gonorrhoea and non-gonococcal urethritis. The data have been analysed quarterly for St. Luke's Clinic (Table II, overleaf) Manchester Royal Infirmary Clinic (Table III, overleaf), and for Manchester for the year ending June 30, 1956 (Table IV, overleaf).

\section{Results}

The experience in the two clinics is essentially uniform and there is little difference between the last three quarters of each year. The third quarter of each year (July to September inclusive) is usually the busiest quarter, and the figures for this quarter in 1955 are not exceptional. Of a total of 3,325 persons, 876 ( 26 per cent.) had consorted with a prostitute. As some men hesitate to admit to association with a prostitute, this percentage is regarded as a minimum figure. The term "prostitute" is used in its narrowest sense and was recorded only in cases in which money was stated to have been given to the woman. (It is interesting to note that the Special Committee of the British Medical Association, responsible for the B.M.A. Memorandum of Evidence (1955) for the Departmental Committee recently set up by the Government, defines female prostitution as "habitually consorting with a variety of men for sexual purposes and for gain in money or kind". I agree with this definition and believe that promiscuous women accepting kind rather than 
TABLE II

ST. LUKE'S CLINIC, MANCHESTER

\begin{tabular}{|c|c|c|c|c|c|c|c|c|c|c|c|c|}
\hline \multirow[b]{2}{*}{ Type of Infection } & \multicolumn{3}{|c|}{ 3rd Quarter, 1955} & \multicolumn{3}{|c|}{ 4th Quarter, 1955} & \multicolumn{3}{|c|}{ 1st Quarter, 1956} & \multicolumn{3}{|c|}{ 2nd Quạrter, 1956} \\
\hline & $\begin{array}{l}\text { Total } \\
\text { Cases }\end{array}$ & $\begin{array}{c}\text { Exposed } \\
\text { with } \\
\text { Prosti- } \\
\text { tute }\end{array}$ & $\begin{array}{c}\text { Exposed } \\
\text { with } \\
\text { Prostitute } \\
\text { (per cent.) }\end{array}$ & $\begin{array}{l}\text { Total } \\
\text { Cases }\end{array}$ & $\begin{array}{c}\text { Exposed } \\
\text { with } \\
\text { Prosti- } \\
\text { tute }\end{array}$ & $\begin{array}{c}\text { Exposed } \\
\text { with } \\
\text { Prostitute } \\
\text { (per cent.) }\end{array}$ & $\begin{array}{l}\text { Total } \\
\text { Cases }\end{array}$ & $\begin{array}{c}\text { Exposed } \\
\text { with } \\
\text { Prosti- } \\
\text { tute }\end{array}$ & \begin{tabular}{|c|} 
Exposed \\
with \\
Prostitute \\
(per cent.)
\end{tabular} & $\begin{array}{l}\text { Total } \\
\text { Cases }\end{array}$ & \begin{tabular}{|} 
Exposed \\
with \\
Prosti- \\
tute
\end{tabular} & $\begin{array}{l}\text { Exposed } \\
\text { with } \\
\text { Prostitute } \\
\text { (per cent.) }\end{array}$ \\
\hline Gonorrhoea $\quad \ldots$ & 311 & 108 & 34 & 187 & 57 & 30 & 171 & 34 & 20 & 249 & 83 & 33 \\
\hline $\begin{array}{l}\text { Non-Gonococcal } \\
\text { Urethritis }\end{array}$ & 139 & 57 & 41 & 97 & 16 & 16 & 107 & 15 & 14 & 135 & 22 & 16 \\
\hline $\begin{array}{c}\text { Other conditions requir- } \\
\text { ing treatment* }\end{array}$ & 127 & 41 & 33 & 126 & 31 & 25 & 113 & 30 & 26 & 126 & 28 & 22 \\
\hline $\begin{array}{c}\text { Other cases not requiring } \\
\text { treatment }\end{array}$ & 171 & 60 & 35 & 157 & 42 & 26 & 152 & 40 & 26 & 185 & 38 & 20 \\
\hline Totals $\ldots$ & 748 & 266 & 35 & 577 & 146 & 25 & 543 & 119 & 22 & 695 & 171 & 25 \\
\hline
\end{tabular}

* All syphilis cases excluded

TABLE III

MANCHESTER ROYAL INFIRMARY CLINIC

\begin{tabular}{|c|c|c|c|c|c|c|c|c|c|c|c|c|}
\hline \multirow[b]{2}{*}{ Type of Infection } & \multicolumn{3}{|c|}{ 3rd Quarter, 1955} & \multicolumn{3}{|c|}{ 4th Quarter, 1955} & \multicolumn{3}{|c|}{ 1st Quarter, 1956} & \multicolumn{3}{|c|}{ 2nd Quarter, 1956} \\
\hline & $\begin{array}{l}\text { Total } \\
\text { Cases }\end{array}$ & $\begin{array}{c}\text { Exposed } \\
\text { with } \\
\text { Prosti- } \\
\text { tute }\end{array}$ & $\begin{array}{c}\text { Exposed } \\
\text { with } \\
\text { Prostitute } \\
\text { (per cent.) }\end{array}$ & $\begin{array}{l}\text { Total } \\
\text { Cases }\end{array}$ & $\begin{array}{c}\text { Exposed } \\
\text { with } \\
\text { Prosti- } \\
\text { tute }\end{array}$ & \begin{tabular}{|c|}
$\begin{array}{c}\text { Exposed } \\
\text { with } \\
\text { Prostitute } \\
\text { (per cent.) }\end{array}$ \\
\end{tabular} & $\begin{array}{l}\text { Total } \\
\text { Cases }\end{array}$ & $\begin{array}{c}\text { Exposed } \\
\text { with } \\
\text { Prosti- } \\
\text { tute }\end{array}$ & $\begin{array}{c}\text { Exposed } \\
\text { with } \\
\text { Prostitute } \\
\text { (per cent.) }\end{array}$ & $\begin{array}{l}\text { Total } \\
\text { Cases }\end{array}$ & $\begin{array}{c}\text { Exposed } \\
\text { with } \\
\text { Prosti- } \\
\text { tute }\end{array}$ & $\begin{array}{c}\text { Exposed } \\
\text { with } \\
\text { Prostitute } \\
\text { (per cent.) }\end{array}$ \\
\hline Gonorrhoea $\quad \ldots$ & 102 & 31 & 30 & 90 & 20 & 22 & 74 & 20 & 27 & 73 & 23 & 31 \\
\hline $\begin{array}{l}\text { Non-Gonococcal } \\
\text { Urethritis }\end{array}$ & 26 & 8 & 30 & 19 & 8 & 42 & 26 & 3 & 13 & 43 & 8 & 19 \\
\hline $\begin{array}{l}\text { Other conditions requir- } \\
\text { ing treatment }\end{array}$ & 17 & 4 & 23 & 22 & 3 & 14 & 22 & 3 & 14 & 15 & 4 & 26 \\
\hline $\begin{array}{c}\text { Other cases not requiring } \\
\text { treatment }\end{array}$ & 57 & 9 & 16 & 71 & 13 & 18 & 58 & 8 & 14 & 57 & 9 & 16 \\
\hline Totals $\ldots$ & 202 & 52 & 25 & 202 & 44 & 22 & 180 & 34 & 19 & 188 & 44 & 23 \\
\hline
\end{tabular}

* All syphilis cases excluded.

TABLE IV

MANCHESTER FOR THE YEAR ENDING JUNE 30, 1956

\begin{tabular}{|c|c|c|c|c|c|c|c|c|c|c|c|c|}
\hline \multirow{2}{*}{\multicolumn{4}{|c|}{ Type of Infection }} & \multicolumn{3}{|c|}{ St. Luke's Clinic } & \multicolumn{3}{|c|}{ Royal Infirmary Clinic } & \multicolumn{3}{|c|}{ Totals } \\
\hline & & & & $\begin{array}{l}\text { Total } \\
\text { Cases }\end{array}$ & $\begin{array}{c}\text { Exposed } \\
\text { with } \\
\text { Prostitute }\end{array}$ & $\begin{array}{c}\text { Exposed } \\
\text { with } \\
\text { Prostitute } \\
\text { (per cent.) }\end{array}$ & $\begin{array}{l}\text { Total } \\
\text { Cases }\end{array}$ & $\begin{array}{c}\text { Exposed } \\
\text { with } \\
\text { Prostitute }\end{array}$ & $\begin{array}{c}\text { Exposed } \\
\text { with } \\
\text { Prostitute } \\
\text { (per cent.) }\end{array}$ & $\begin{array}{l}\text { Total } \\
\text { Cases }\end{array}$ & $\begin{array}{c}\text { Exposed } \\
\text { with } \\
\text { Prostitute }\end{array}$ & $\begin{array}{l}\text { Exposed } \\
\text { with } \\
\text { Prostitute } \\
\text { (per cent.) }\end{array}$ \\
\hline Gonorrhoea & $\ldots$ & $\ldots$ & $\cdots$ & 918 & 282 & 30 & 339 & 94 & 28 & 1,257 & 376 & 30 \\
\hline Non-Gonococ & ccal & rethritis & $\cdots$ & 478 & 110 & 23 & 114 & 27 & 24 & 592 & 137 & 23 \\
\hline $\begin{array}{l}\text { Other conditi } \\
\text { treatment }\end{array}$ & ions & $\begin{array}{l}\text { quiring } \\
\ldots\end{array}$ & $\ldots$ & 492 & 130 & 28 & 76 & 14 & 18 & 568 & 144 & 24 \\
\hline $\begin{array}{c}\text { Other cases } \\
\text { treatment }\end{array}$ & not & $\begin{array}{l}\text { uiring } \\
\ldots\end{array}$ & $\ldots$ & 665 & 180 & 27 & 243 & 39 & 16 & 908 & 219 & 24 \\
\hline Totals $\ldots$ & $\ldots$ & $\cdots$ & $\cdots$ & 2,553 & 702 & 27 & 772 & 174 & 23 & 3,325 & 876 & 26 \\
\hline
\end{tabular}

* All syphilis cases excluded.

money are prostitutes in effect although not in law; in relation to the spread of venereal disease they play an important part which will be discussed in a later communication.) In many cases the actual sum was noted: it varied from $2 s$. to $£ 6$; exposures outside cost up to $£ 2$ while exposures inside in a hotel bedroom, the woman's apartment, or a rented
The 876 exposures to risk of infection from prostitutes resulted in 376 infections with gonorrhoea, 137 infections with non-gonococcal urethritis, and 144 minor conditions requiring some treatment. The remaining 219 cases attended for exclusion of infection and reassurance (Table $\mathrm{V}$, opposite). 
TABLE V

RESULTS OF EXPOSURE WITH PROSTITUTES IN 876 CASES

\begin{tabular}{|c|c|c|c|c|c|c|}
\hline Clinic & Period & $\begin{array}{l}\text { Number of } \\
\text { Exposures }\end{array}$ & Gonorrhoea & $\begin{array}{c}\text { Non-Gonococcal } \\
\text { Urethritis }\end{array}$ & $\begin{array}{l}\text { Other Conditions } \\
\text { Requiring } \\
\text { Treatment }\end{array}$ & $\begin{array}{c}\text { Other Cases not } \\
\text { Requiring } \\
\text { Treatment }\end{array}$ \\
\hline \multirow{5}{*}{$\begin{array}{l}\text { St. Luke's } \\
\text { Clinic }\end{array}$} & 3rd Quarter, 1955 & 266 & 108 & 57 & 41 & 60 \\
\hline & 4th Quarter, 1955 & 146 & 57 & 16 & 31 & 42 \\
\hline & 1st Quarter, 1956 & 119 & 34 & 15 & 30 & 40 \\
\hline & 2nd Quarter, 1956 & 171 & 83 & 22 & 28 & 38 \\
\hline & Totals & 702 & 282 & .110 & 130 & 180 \\
\hline \multirow{5}{*}{$\begin{array}{c}\text { Manchester } \\
\text { Royal } \\
\text { Infirmary } \\
\text { Clinic }\end{array}$} & 3rd Quarter, 1955 & 52 & 31 & 8 & 4 & 9 \\
\hline & 4th Quarter, 1955 & 44 & 20 & 8 & 3 & 13 \\
\hline & 1st Quarter, 1956 & 34 & 20 & 3 & 3 & 8 \\
\hline & 2nd Quarter, 1956 & 44 & 23 & 8 & 4 & 9 \\
\hline & Totals & 174 & 94 & 27 & 14 & 39 \\
\hline & Grand Totals & 876 & 376 & 137 & 144 & 219 \\
\hline
\end{tabular}

Further analysis with regard to place of infection has shown that 85 per cent. of these exposures with prostitutes took place in Manchester. One half of the remainder (7 per cent.) occurred in other English cities, chiefly London and Liverpool, and the remaining 8 per cent. in foreign cities.

\section{Discussion}

The data presented above show that in Manchester a quarter of all male patients attending the V.D. clinics do so after exposure with a prostitute. Furthermore, 30 per cent. of male cases of gonorrhoea and almost a quarter of the cases of nongonococcal urethritis are infected by prostitutes. Some prostitutes attend the V.D. clinics at irregular intervals on their own initiative but the number is small. It is usually impossible to bring the source of infection of a male case of gonorrhoea to treatment when he has been exposed with a prostitute as the economic basis of the association does not encourage acquaintance with those personal particulars which would assist in contact tracing. There is no doubt that the prostitute contributes substantially to the "reservoir" of untreated female gonorrhoea and that treatment of the prostitute would assist significantly in the control of gonorrhoea in Manchester. Police action against soliciting is handicapped by the unsatisfactory state of the law and, on conviction, the imposition of the maximum fine of forty shillings sets the woman free to recoup her fine at the expense of the health of the public. It would be logical and helpful if Magistrates were to recommend attendance at the V.D. clinics for examination and treatment, perhaps at special sessions of the clinic. This is currently done throughout Canada and in many cities in the U.S.A., the examination room often being situated in the same building as the Court. It is sincerely hoped that the Report of the Departmental Committee, which is at present considering the law and practice relating to homosexuality and prostitution, will include recommendations on this aspect of the problem of prostitution, and that realistic legislation will permit police and Magistrates to discourage prostitution and assist in the control of venereal disease.

\section{SUMmarY}

Data from the special study, which is being made of the epidemiological and social aspects of venereal diseases, show that in Manchester 30 per cent. of male cases of gonorrhoea and the attendance of a quarter of all male patients at the major V.D. clinics result from exposure with prostitutes. Altogether 85 per cent. of these exposures with prostitutes took place in Manchester.

As it is usually impossible to effect the attendance of the prostitute at the V.D. clinic through the infected male client, it is urged that police action against prostitution should be encouraged by more realistic legislation, and that Magistrates should recommend the prostitute to report to the V.D. clinic for examination.

I wish to thank Mr. J. Payton and Mr. A. Tattersall of St. Luke's Clinic for their work in transcribing the information to the special register.

\section{REFERENCES}

B.M.A. Memorandum (1955). Brit. med. J., 2, Suppl., 169.

British Clínical Cooperative Group Gonorrhoea Study (1956). British Clinical Cooperative Group Gournal of Venereal Diseases, 32, 21.

British Journal of Venereal Diseases, $32,21$.
British Social Biology Council (1955). "Women of the Streets: A Sociological Study of the Common Prostitute", p. 93. Ed. by C. H. Rolph. Secker and Warburg, London.

Nicol, C. S. (1956). British Journal of Venereal Diseases, 32, 27. 